The Catholic University of America, Columbus School of Law

CUA Law Scholarship Repository

1993

\title{
'Posterity' in the Preamble and a Positivist Pro-Life Position
}

Raymond B. Marcin

The Catholic University of America, Columbus School of Law

Follow this and additional works at: https://scholarship.law.edu/scholar

Part of the Constitutional Law Commons, and the Natural Law Commons

\section{Recommended Citation}

Raymond B. Marcin, 'Posterity' in the Preamble and a Positivist Pro-Life Position, 38 AM. J. JURIS. 273 (1993).

This Article is brought to you for free and open access by the Faculty Scholarship at CUA Law Scholarship Repository. It has been accepted for inclusion in Scholarly Articles and Other Contributions by an authorized administrator of CUA Law Scholarship Repository. For more information, please contact edinger@law.edu. 


\title{
"POSTERITY" IN THE PREAMBLE AND A POSITIVIST PRO-LIFE POSITION
}

\author{
RAYMOND B. MARCIN
}

\section{INTRODUCTION}

The ARGUMENTS FOR AND AGAINST the continuing vitality of Roe $v$. Wade $^{1}$ are characterizable as either natural law or positivist in tone. ${ }^{2}$ Indeed the Roe decision itself, based as it is in the doctrine of substantive due process, has been characterized as an example of natural law reasoning, although those who defend it usually do so in positivist terms.

Arguments for the overturning of the Roe decision can be grouped into two categories: (1) the positivist argument that, contrary to the assertions in the Roe decision, ${ }^{3}$ nothing in the Constitution protects the right to privacy in the abortion decision (thus leaving legislatures free to regulate the matter), and (2) the natural law argument that a fetus or unborn child has a fundamental and inalienable right to life (thus preventing legislatures from regulating the matter, except for compelling governmental reasons). The right-to-life movement is

1. 410 U.S. 113 (1973).

2. Natural law jurisprudence suggests the existence of a higher law to which all human law, whether in the form of legislation or case law, is subservient and on which all human law depends for its validity. Natural law jurists purport to discover this higher law in understandings of human nature itself. Natural law jurisprudence has a history of a connection with religious views of law and justice. See, e.g., Thomas Aquinas, Summa theologiae, q. 90-97. In both its later and earlier forms, however, natural law jurisprudence'existed without reference to religious doctrine. See Marcus Tullius Cicero, On the Commonwealth, Bk. III, ch. 13; and Hugo Grotius, De Jure Belli Ac Pacis (1625). Positivist jurisprudence suggests that law is confined to that which is posited or declared to be such by an authority competent to do so. See Jeremy Bentham, An Introduction to the Principles of Morals and Legislation (1780). In the context of the issues involved in Roe v. Wade, a natural law approach would find the rights being discussed, whether the pregnant woman's right to privacy in the abortion decision or the right to life of the fetus or unborn child, in higher-law-type understandings of humanness, without any necessary reference to the Constitution, whereas a positivist approach would, for its conclusions regarding those rights, rely on the concepts and principles which are found in the Constitution, and would eschew any appeal to a higher-law concept.

3. Justice Blackmun, for the majority in Roe, located the right to privacy in the abortion decision "in the fourteenth amendment's concept of personal liberty and restrictions on state action." 410 U.S. 153 (1973). 
grounded upon the latter, natural law position. The difficulty for the pro-life movement is that, if the Court decides to overrule Roe, it will most likely do so using a positivist rather than a natural law rationale.

Attempts have been made to cast a positivist gloss on the argument that the fetus or unborn child has a right to life, usually by identifying the right to life in question with the rights to life posited in the language of the fifth and fourteenth amendments. Those attempts, however, have usually bogged down in question-begging circularity. The fifth and fourteenth amendments' rights to life inure to "persons," and a fetus may or may not be a person, depending on the medical, philosophical, or theological perspective one holds. The Roe Court itself, noting the lack of a medical, philosophical, or theological consensus on that issue, has declared that it (the Court) is not in a position to impose an answer to that pivotal question as to when human life begins, ${ }^{4}$ but it has given a negative answer to the question as to whether the fetus is a "person" in the constitutional sense."

The Court's disinclination to come to grips with the question of human life and its negative ruling on constitutional personhood ${ }^{6}$ have been frustrating to those who oppose the Roe decision. Some have taken the critical natural law stance that if there is genuine doubt as to whether a given entity is a human being or a person, any truly civilized society would resolve that doubt in favor of humanness and personhood rather than against them, lest the society find itself approving of homicide. Others have taken the position that, by not answering the question of when human life begins, the Court has really answered it by positive inaction. In truth, however, the Court had little to go on from a positivist perspective, except the Constitution's confinement of the right to life to "persons" and the common-law precedents which failed to grant personhood to fetuses on any consistent and unequivocal basis. ${ }^{7}$

The purpose of this article is to proffer the suggestions that the question of human personhood in yet-to-be-born people has never been unanswerable in terms of the text of the Constitution; that the

4. Ibid., p. 159. Elsewhere in the opinion, the Court took the position that "person" as used in the text of the Constitution does not have any possible prenatal application. Ibid., p. 157.

5. Ibid., p. 158.

6. Ibid.

7. The Court in Roe did, however, allow the obvious, i.e., that if constitutional personhood were established, the fetus' right to life would then be guaranteed by the fourteenth amendment. Ibid., p. 157. 
text of the Constitution itself indeed either posits the answer or contains a criterion for positing the answer (an answer and a criterion which were not considered in the Roe decision); and that the answer posited is a pro-life answer, i.e., it is consistent with the proposition that the Constitution can and perhaps should be interpreted in such a way as to protect the right to life of fetuses or unborn children.

\section{Posterity and the Preamble}

The textual reference will at first seem to the reader to be a modest one. The reference is to the Preamble to the Constitution which, in pertinent part, reads:

We the People of the United States, in Order to ... secure the Blessings of Liberty to ourselves and our Posterity, do ordain and establish this Constitution for the United States of America. ${ }^{8}$

A reference to the Preamble to the Constitution in the context of the Roe decision is neither new nor original. Justice Douglas' concurrence in Doe v. Bolton" posited the "Blessings of Liberty" clause in the Preamble as one of the textual locations of the right to privacy in the abortion decision, and as the location of a far broader right of privacy than was necessary to the Roe decision. ${ }^{10}$ Douglas, however, used only a part of the clause. The full text of the clause indicates that the entire Constitution was ordained and established, inter alia, to secure the blessings of liberty to two classes of people, i.e., "ourselves" and "our Posterity." The focus of this article is on the word "Posterity," and the word "Posterity,""11 it is suggested, is difficult to define except in terms of yet-to-be-born people. To put the matter quite simply, from a textualist perspective, the conclusion seems inescapable that one of the purposes for the establishment of our Constitution, identified as such in the Preamble, is to secure the blessings of liberty to yet-to-be-born persons. ${ }^{12}$

8. U.S. Constitution, Preamble.

9. 410 U.S. 179 (1973). Justice Douglas' concurrence in Doe also applies to Roe. Ibid., p. 209.

10. Ibid., p. 209.

11. Webster's Third International Dictionary defines "posterity" as "the offspring of one progenitor to the furthest generation" or "descendants," and cites and quotes the "blessings of liberty" clause in the Preamble to the Constitution as its example. Webster's Third International Dictionary (1981), p. 1772.

12. At one point in his majority opinion in Roe, Justice Blackmun contended that none of the usages of the word "person" in the Constitution indicates, with any assurance, that the word has any possible prenatal application. 410 U.S. 113 (1973). Blackmun catalogued all the instances in which the word "person" is used 
It would be disingenuous in the extreme to suggest that the word "Posterity" somehow refers exclusively to fetuses. Quite obviously the framers intended the word to refer to the generations yet to come, the descendants of the people of the United States of America (and perhaps not even in an exclusively biological sense). In that context, however, and even with that gloss of understanding, the clause represents a textually specific indication that the Constitution was intended, and presumably should be understood and interpreted, to secure "Blessings of Liberty" to descendants as yet unborn. Indeed it is not disingenuous to suggest that the Constitution places two classes of people on a par in terms of entitlement to the "Blessings of Liberty," i.e., "ourselves" and "our Posterity."

The word "posterity," by the year 1788 , could be found in many of the great documents founding and establishing the governments of the new incipient states. The Preamble to the Massachusetts Bill of Rights in 1780 , for example, not only contained a "We ... the people" clause, but also recognized "the goodness of the great Legislator of the universe" in affording the people an opportunity "of forming a new constitution of civil government for ourselves and posterity."'13 Pennsylvania's Constitution of 1776, completed on September 28, 1776, contained a similar reference to "posterity," announcing that "it is our indispensable duty to establish such original principles of government, as will best promote the general happiness of the people of this State, and their posterity. . ."14

The original and most helpful reference to "posterity" in the context of the emerging independence movements, ${ }^{15}$ however, came

in the Constitution, and made no reference to the Preamble because the word "person"' does not appear there (although the word "people" obviously does). The position taken in this article is that the reference to "Posterity" in the Preamble (not referred to by Justice Blackmun and apparently not considered by the Court in Roe) necessarily casts a gloss of meaning on all the references to "person" and "life" and "liberty" and similar usages in the main text of the Constitution, a gloss that the Court has not yet taken into account in its past decisions.

13. The Federal and State Constitutions, Colonial Charters, and Other Organic Laws of the United States (Perley Poore, ed. 1877).

14. Ibid, p. 1541.

15. Earlier references to "posterity" in the context of fundamental rights movements exist. The "Body of Liberties of the Massachusets Collonie in New England" of 1641 contains an example:

We hould it ... our dutie and safetie whilst we are about the further establishing of this Government to collect and expresse all such freedomes as for present we foresee may concerne us, and our posteritie after us. . . .

Quoted in The Founder's Constitution (Philip B. Kurland and Ralph Lerner, eds. 1987), vol. 1, p. 428 [emphasis added]. 
in June of 1776 in the Virginia Declaration of Rights. Drafted by George Mason, who was later to become one of Virginia's delegates to the Federal Constitutional Convention of 1787, the Virginia Declaration of Rights proclaimed in its Preamble that the rights declared in the purview of the instrument "do pertain to them (i.e., 'the good people of Virginia') and their posterity, as the basis and foundation of government."16 The first substantive clause of the Declaration mentions "posterity" in strongly operative terms: "[A]ll men are by nature equally free and independent, and have certain rights, of which, when they enter into a state of society, they cannot by any compact deprive or divest their posterity; namely the enjoyment of life and liberty, with the means of acquiring and possessing property, and pursuing and obtaining happiness and safety." 17 . The emphasized language gains some importance when one realizes that at the time the original body of the United States Constitution was approved, there was no "Bill of Rights" in it, and thus the "Blessings of Liberty" clause can only have been understood either in the positivist context of the then extant state declarations and bills of rights or in natural law understandings of the concept of liberty. If the clause is understood in the positivist context, it is clear that at least some of the state declarations and bills of rights gave the term "posterity" genuine operative significance; e.g., under Virginia's Declaration, posterity could not be divested of certain rights like the rights to life and liberty.

\section{Two ARguments AND A COROLlaRY}

Two arguments suggest themselves as a result of the analysis thus far, one a somewhat aggressive argument, and the other a bit less ambitious. The aggressive argument would be based on the fact that the word "Posterity" includes (but, of course, is not limited to) fetuses. That argument would go something like this. The "People of the United States" in 1788, when they ordained and established the Constitution, did so in order to secure the blessings of liberty to their yet-to-be-born descendants. Their yet-to-be-born descendants included those who were then in utero as well as the innumerable generations yet to come into existence. Both classes of descendants fit in under the term "Posterity." In this argument, the Preamble clause is urged as a textually demonstrable indication that the

16. The Federal and State Constitutions, Colonial Charters, and Other Organic Laws of the United States, p. 1098.

17. Ibid. (emphasis added). 
Constitution was intended to secure "Blessings of Liberty" for fetuses. Under this argument the full weight of the Preamble stands behind the proposition that "Posterity" (in the form both of notyet-existent descendants and existent-but-not-yet-born descendants) merits the "Blessings of Liberty." This argument is flawed, partly because it proves too much (carried to its logical conclusion, it would undo both Griswold ${ }^{18}$ and Eisenstadt ${ }^{19}$ - there is no textual reason why the "Blessings of Liberty" do not inure to the yet-to-beconceived portion of "Posterity"), and partly because it gives direct operative effect to the Preamble, and the Preamble, as we shall see infra, cannot be used as an independent source of constitutional rights and powers, but can only be used to elucidate those which do appear in the purview of the Constitution.

The less ambitious argument would be less textualist or intentist in scope, and would draw on the "spirit and reason" rule ${ }^{20}$ as well as the more contemporary purposive, narrative, or "evolutionary" models of legislative interpretation..$^{21}$ It would allow that the ordainers and establishers of the Constitution might not have had the specific problem of the right to life of existent-but-not-yet-born descendants in mind, whether because abortion was not then a current issue or because they simply intended a reference to future generations in a generalized sense. Even under those hypotheses, however, the clause is an indication that the ordainers and establishers wanted the Constitution to be understood into the indefinite future to be as much "Posterity"-oriented as "selves"-oriented. 22

18. Griswold v. Connecticut, 381 U.S. 479 (1965).

19. Eisenstadt v. Baird, 405 U.S. 438 (1972).

20. See generally Holy Trinity Church v. United States, 143 U.S. 457 (1892).

21. See William N. Eskridge and Philip P. Frickey, Cases and Materials on Legislation: Statutes and the Creation of Public Policy (1988), pp. 613-18; William N. Eskridge and Philip P. Frickey, "Statutory Interpretation as Practical Reasoning," 42 Stan. L. Rev. (1990), p. 321; and Dennis M. Patterson, "Law's Pragmatism: Law as Practice and Narrative," $76 \mathrm{Va} . \mathrm{L}$. Rev. (1990), p. 937.

22. Justice Joseph Story, writing specifically about the "Blessings of Liberty to ourselves and our Posterity" clause, observed that:

[S]urely no object could be more worthy of the wisdom and ambition of the best men of any age. If there is any thing, which may justly challenge the admiration of all mankind, it is that sublime patriotism, which looking beyond its own times, and its own fleeting pursuits, aims to secure the permanent happiness of posterity by laying the broad foundations of government upon immovable principles of justice. . . [T] [Tere is a noble disinterestedness in that forecast, which disregards present objects for the sake of all mankind, and erects structures to protect, support, and bless the most distant generations.

Joseph Story, Commentaries on the Constitution of the United States (abridged ed. 1833), p. 189. 
Under this analysis, admittedly less ambitious than the former, the Court, when faced with an interpretive question which could be resolved in a way in which the concept of "Posterity" is (1) taken positively and protectively into account, that is, an interpretation which is posterity-oriented, at least in part, or (2) ignored or treated negatively, would in light of the "Blessings of Liberty" clause ordinarily choose the former. This argument is more negative than positive in its casting, stressing only that interpretations which ignore or treat negatively the interests of "Posterity," or which fail to put "Posterity" on the same level as "selves," are very likely not in accord with the spirit of the Constitution. It does not suggest that "Posterity" has some affirmative claim to rights or entitlements. As applied to the Roe decision, however, the argument carries some force. In Roe the Court was faced with at least two plausible choices, ${ }^{23}$ one of which-extending fourteenth-amendment right-to-life coverage to fetuses-was posterity-oriented in that it would have taken the interests of a portion of posterity positively and protectively into account, and the other of which-withholding fourteenth-amendment right-to-life coverage from fetuses-could hardly be said to be posterity-oriented or even to put "Posterity" on the same level as "selves," in that it recognized no protectable interests of the portion of posterity in question (it did, however, recognize an interest of the government in potential human life). The Court chose that latter interpretation, and in doing so (so the argument would go) was not in accord with the spirit of the Constitution as informed by the "Blessings of Liberty to . . . our Posterity" clause.

A corollary to this second argument would be that a legislature which chooses to protect potential human life from the moment of conception can hardly be said to be acting against the spirit of the Constitution as that spirit is informed by the "Blessings of Liberty to ... our Posterity" clause.

Both arguments and the corollary lead inexorably to a clash between two of the phrases in the fourteenth amendment's due process clause, i.e., the right to liberty, which may well include a right to privacy in the abortion decision in the abstract, and the right to life, which according to a reading of the spirit of the Constitution

23. A third choice was to leave the matter to the legislatures, but that choice is not relevant to the perspective being explored in this article. In that context, however, choosing to leave the matter to the legislatures would amount merely to a postponement of the interpretive problem. The constitutionality of the legislatures' work products, be they pro-life, pro-choice, or something in between, would still have to be assessed in light of the blessings-of-liberty and right-to-life clauses. 
informed by the "Blessings of Liberty to . . our Posterity" clause may well include a right of an unborn yet nonetheless extant unit of posterity to enter the outer world so that she can enjoy those blessings. ${ }^{24}$ In the strongest understanding of this clash, the right to life must always trump the right to liberty and can only be undone if the right to liberty in the equation also happens to amount to a right to life, i.e., if the continued life of the fetus is a genuine threat to the life of the pregnant woman. The principle of self-defense in the context of a genuine threat to one's life would alone justify the taking of the fetus' life. Weaker understandings are certainly possible. Quality-of-life considerations can be let into the balance, but only at the risk of turning the "Blessings of Liberty to . . . our Posterity" clause into a contentless derelict in the text of the Preamble. What seems evident is that the "Blessings of Liberty to . . . our Posterity" clause identifies us as a people who profess a caring attitude toward our descendants to the point of announcing formally and solemnly that the fundamental document of our structured self-government was ordained and established for their weal as well as ours, and so that they may enjoy what we enjoy.

\section{The Authority of the Preamble}

One might expect that not much has been written about the Preamble of the United States Constitution, and even less about the "Blessings of Liberty" clause, and those suspicions would not be far off the mark. The "Blessings of Liberty" clause has, however, received fairly recent comment in Justice Douglas' concurrence in Doe v. Bolton. ${ }^{25}$ Apart from Douglas' reference, Justice Harlan referred to the clause in Jacobson v. Massachusetts:

Although . . . one of the declared objects of the Constitution was to secure the blessings of liberty to all under the sovereign jurisdiction and authority of the United States, no power can be exerted to that end by the United States unless, apart from the Preamble,

24. The more aggressive argument would position that right to life in the "Blessings of Liberty to . . . our Posterity" clause itself. The less aggressive argument would position it in the "right to life" clauses and would only use the "Blessings of Liberty to ... our Posterity" clause as an interpretive aid, identifying the spirit and reason behind the Constitution's recognition of the right to life as being as much "Posterity"'-oriented as "selves"-oriented.

25. 410 U.S. 179 (1973). 
it be found in some express delegation of power or in some power to be properly implied therefrom. 1 Story's Const. sec. $462 .{ }^{26}$

Justice Harlan's reference to Joseph Story's Commentaries on the Constitution of the United States underscores the basic principle that the Preamble may not be referred to in order to enlarge the powers given in the purview of the instrument, but that it is permissible to use the Preamble to discover the object or purpose of the framers:

It is an admitted maxim in the ordinary course of the administration of justice, that the Preamble of a statute is a key to open the mind of the makers, as to the mischiefs, which are to be remedied, and the objects, which are to be accomplished by the provisions of the statute... There does not seem any reason, why, in a fundamental law or constitution of government, an equal attention should not be given to the intention of the framers, as stated in the Preamble. ${ }^{27}$

The example chosen by Justice Story to illustrate this principle, although not in the context of the "Blessings of Liberty" clause, is instructive:

For example, the Preamble declares one object to be, "to provide for the common defence." ... [S]uppose the terms of a given power admit of two constructions the one more restrictive, the other more liberal, and each of them is consistent with the words, but is, and ought to be, governed by the intent of the power; if one would promote, and the other defeat the common defence, ought not the former, upon the soundest principles of interpretation to be adopted? Are we at liberty, upon any principles of reason, or common sense, to adopt a restrictive meaning, which will defeat an avowed object of the constitution, when another equally natural, and more appropriate to the object, is before us?

26. 197 U.S. 11, 22 (1905). Various aspects of the Preamble are discussed in other decisions of the United States Supreme Court. See Chisholm v. Georgia, 2 U.S. (2 Dall.) 471 (1793); Martin v. Hunter's Lessee, 14 U.S. (1 Wheat.) 324 (1816); McCulloch v. Maryland, 17 U.S. (4 Wheat) 403 (1819); Barron v. Baltimore, 32 U.S. (7 Pet.) 247 (1833); Leggue v. DeYoung, 52 U.S. (11 How.) 203 (1850); Texas v. White, 74 U.S. (7 Wall.) 724 (1869); Legal Tender Cases, 79 U.S. (12 Wall.) 554 (1871); White v. Hart, 80 U.S. (13 Wall.) 650 (1872); United States v. Cruikshank, 92 U.S. 542 (1876); Yick Wo v. Hopkins, 118 U.S. 369 (1886); Geofroy v. Riggs, 133 U.S. 258 (1890); In re Ross, 140 U.S. 464 (1891); De Lima v. Bidwell, 182 U.S. 1 (1901); Goetze v. United States, 182 U.S. 221 (1901); Dooley v. United States, 182 U.S. 236 (1901); Downes v. Bidwell, 182 U.S. 270 (1901); Ponce v. Roman Catholic Apostolic Church, Porto Rico, 210 U.S. 296 (1908); and Ochoa v. Morales, 230 U.S. 139 (1913). The Jacobson case, however, is the one which contains the major pronouncements on the "Blessings of Liberty" clause and on the interpretive principle with respect to the Preamble.

27. Commentaries on the Constitution of the United States, sec. 218, 219. 
Would not this be to destroy an instrument by a measure of its words, which that instrument itself repudiates? ${ }^{28}$

If it is fair to paraphrase Justice Story's analysis and apply it to the "Blessings of Liberty" clause, one might argue the following. Suppose that the provisions in the Constitution recognizing a right to life admit of two constructions, the one more restrictive, the other more liberal, and each of them is consistent with the words, but is, and ought to be, governed by the intent of those provisions; if one would secure, and the other defeat the securing of the blessings of liberty to our posterity, ought not the former, upon the soundest principles of interpretation to be adopted?

The question remains as to whether Story's principle of interpretation with respect to Preambles is indeed sound. Story himself, at one point, referred to the Preamble somewhat sanguinely as "very important, not only as explanatory of the motives and objects of framing the Constitution; but as affording the best key to the interpretation thereof." 29 A contemporary constitutional scholar, however, while not inconsistent with Story, is somewhat less sanguine:

The Preamble to the Constitution of the United States illuminates the objects of the Framers and, thus, can be a guide to construction, but it is not considered to confer powers or right. ${ }^{30}$

In truth, the law of legislative interpretation has given Preambles a mixed reception. The early English cases gave them great weight for statutory interpretation purposes. ${ }^{31}$ The idea that Preambles ought to be used only to explicate, and not as a source of positive powers, seems to have entered our jurisprudence in the eighteenth century. ${ }^{32}$ That limitation is what brought the law on Preambles to its present state, recognizing them as useful in identifying the spirit and reason behind a particular piece of legislation, but not as conferring positive rights or powers.

[I]t is to the Preamble more especially that we look for the reason, or spirit, of every statute; rehearsing, ... as it ordinarily does,

28. Ibid., sec. 221 (emphasis added). The quote here is from the abridged version of Story's Commentaries. It is not without significance to note that the section referred to here is, in the differently numbered unabridged version, section 462 , i.e., the section cited by Justice Harlan in the Jacobson case. See ibid., conversion table, p. xxxvii.

29. Commentaries on the Constitution of the United States, p. 37, 38 (emphasis added).

30. Chester James Antieu, Constitutional Construction (1982), p. 31.

31. See Stowel v. Lord Zouch, 1 Plowd. 353, 369, 75 Eng. Rep. 536 (C.B. 1569).

32. See Copeman v. Gallant, 1 P. Wms. 314, 24 Eng. Rep. 404 (Ch. 1716). 
$\ldots$ in the best and most satisfactory manner, the object or intention of the legislature. ${ }^{33}$

The lesson from the case law on Preambles in general seems to be that Preambles are of limited use in legislative interpretation. They are not ordinarily regarded as controlling when they contradict the purview of the text, and they cannot be looked to as sources of rights or powers independent of those specified in the purview, but in cases of doubt, where there is ambiguity or uncertainty in the purview proper, they can be resorted to as aids in discovering the spirit and reason behind the rule or principle in question. ${ }^{34}$

In light of the case law on Preambles in general and on the Preamble to the Constitution of the United Statês in particular, it would seem that some limited use may be made of the "Blessings of Liberty to ... our Posterity" clause in shedding light on the spirit behind the fifth and fourteenth amendments' rights to life and liberty. ${ }^{35}$ In that context, some understanding of the "legislative history" behind the Preamble and the "Blessings of Liberty" clause would seem to be relevant.

33. Brett v. Brett, 3 Add. 210, 216, 162 Eng. Rep. 456 (Ch. 1716).

34. See generally Sutherland, Statutory Construction (4th ed. 1984), vol. 2A, sec. 47.04 , pp. 126-31. There has been some sentiment to the contrary in the history of Congress' treatment of the Preamble. In the debates over amending the Constitution to insert a bill of rights, in August of 1789, a proposal was introduced to insert, before "We the People" in the Preamble the words "Government being intended for the benefit of the people and the rightful establishment thereof being derived from their authority alone." The proposal, of course, was eventually rejected, but during the debates, Thomas Tudor Tucker, the representative from South Carolina, argued that the Preamble "was no part of the Constitution," but others, notably, Roger Sherman of Connecticut, argued that the amendment was unnecessary because the "We the People" language already expressed its principle. Tucker's statement was, at best, an understatement of the authoritativeness of preambles, even in the case law of his day. Sherman and those who agreed with him, in any case, took a position that did give operative effect to the Preamble. See Creating the Bill of Rights: The Documentary Record from the First Federal Congress (Helen E. Veit et al, eds. 1991), p. 129.

35. It is, of course, a fact that neither the fifth amendment's nor the fourteenth amendment's right-to-life clause was in the Constitution at the time of its adoption, but the amendatory process itself was laid out in the original text, and thus it would be disingenuous to suggest that the Preamble expresses the spirit and reason behind the original body of the document, but not the spirit and reason behind later amendments, unless, of course, the later amendment can be understood as abrogating expressly or impliedly something in the original text. Also, as we shall see, the legislative history of the "Blessings of Liberty" clause reveals that it is tied in with the declarations or bills of rights in the various state constitutions, including, of course, their specific guarantees of rights to life and liberty. 


\section{The Legislative History of the Preamble}

The "Blessings of Liberty" clause, it may come as a surprise to some, was not in any of the early drafts of the Constitution during the Convention of 1787 . In fact, it entered very late in the proceedings, in mid-September of 1787 , just a few days before the final version of the Constitution was signed by the delegates and sent to the state ratifying conventions. As of September 10,1787, the Convention had all but agreed on a final text of the Constitution when a motion was passed to appoint a committee "to revise the stile of and arrange the articles which had been agreed to by the house." 36 The Preamble to the version of the draft Constitution that was referred to this Committee of Style did mention the world "Posterity," but contained no "Blessings of Liberty" clause:

We the people of the States of New-Hampshire, Massachusetts, Rhode Island and Providence Plantations, Connecticut, New-York, New-Jersey, Pennsylvania, Delaware, Maryland, Virginia, NorthCarolina, South-Carolina, and Georgia, do ordain, declare and establish the following Constitution for the government of ourselves and our Posterity. ${ }^{37}$

Four days later, on September 12, 1787, the Committee of Style reported on its work, and presented the Convention with the text of the Constitution in virtually the form in which we see it today (without the Bill of Rights and the later amendments, of course), with its present Preamble. ${ }^{38}$ The convention adopted the Constitution five days later.

36. The Records of the Federal Convention of 1787 (Max Farrand, ed. 1937), vol. 2 , p. 553.

37. Ibid., p. 565 . Nott has suggested that the version quoted here was the work of Charles Pinckney, the delegate from South Carolina, and was derived from the Constitution of Massachusetts. Charles C. Nott, The Mystery of the Pinckney Draught (1908), p. 167, 169. The version quoted here was actually agreed to without debate by the Convention on August 7, 1787. See The Records of the Federal Convention of 1787, vol. 2, p. 209; and Documents Illustrative of the Formation of the Union of the American States (Charles C. Tansill, ed. 1927), p. 482. Elliot reports that "[o]n the question to agree to the preamble to the Constitution as reported from the committee [of detail] to whom were referred the proceedings of the Convention, it passed unanimously in the affirmative." The Debates in the Several State Conventions on the Adoption of the Federal Constitution as Recommended by the General Convention at Philadelphia in 1787 Together with the Journal of the Federal Convention (Jonathan Elliot, ed. 1836), pp. 230, 231.

38. Van Doren has referred to the present Preamble as "[t]he most striking addition made by the Committee of Style." Carl Van Doren, The Great Rehearsal: The Story of the Making and Ratifying of the Constitution of the United States (1948), p. 160. 
It is generally acknowledged that the individual author of the Committee of Style's new Preamble (the one that we see today in the Constitution) was Gouverneur Morris of Pennsylvania. ${ }^{39}$ Morris undoubtedly would have been familiar with the Constitution of Pennsylvania of 1776 which, in its Preamble, mentions "posterity" and, in its declaration of rights, mentions "the blessings of liberty":

[I]t is our indispensable duty to establish such original principles of government, as will best promote the general happiness of the people of this state, and their posterity. . . . A frequent recurrence to fundamental principles, and a firm adherence to justice, moderation, temperance, industry, and frugality are absolutely necessary to preserve the blessings of liberty, and keep a government free. . . . ${ }^{40}$

Morris may or may not have drawn on the language of his home state's constitution in drafting the Preamble to the United States Constitution, but the more interesting question is why he chose to make any alteration at all in the Committee of Detail's Preamble, especially in view of the fact that that version of the Preamble had been voted on and already approved by the Convention.

The history of what happened in the Committee of Style during the four days in which it worked on and revised the text of the Constitution is not well recorded, and with respect to the changes in the wording of the Preamble, even less well recorded. One is left with surmises and inferences drawn mainly from records of reactions of various delegates to the Committee's final draft on the floor of the Convention and afterwards. Perhaps the most strident of the reactions to the change in the wording of the Preamble came from Luther Martin, the delegate from Maryland, in an article in the Maryland Gazette on June 3, 1788, nearly a year after the deed had been done. Martin still felt strongly enough to juxtapose the two versions of the Preamble (the one in the draft submitted to the Committee of Style and the one reported out by that committee) and to accuse the committee of trying to destroy the several state governments (Martin, of course, was not a signatory to the Constitution and argued against its approval):

As altered, every appearance of the existing governments, under their respective Constitutions, is relinquished, the very names struck out, general purposes and powers given extending to every

39. See The Records of the Federal Convention of 1787, pp. 170, 420, 499.

40. The Federal and State Constitutions, Colonial Charters, and Other Organic Laws of the United States, pp. 1541, 1542 (emphasis added). 
purpose of the social compact, and then this Constitution including all these purposes, is made the Constitution of the United States, without any reserve of the several States or their Constitutions then existing, and then this Constitution enacted for these unlimited purposes, we afterwards find is expressly declared paramount to all Constitutions, and laws existing in the States.41

It seems probable that Luther Martin regarded all the clauses of the present Preamble as amounting together to something like a national bill of rights preempting of all the states' declarations and bills of rights, when he wrote of the Preamble's "general purposes and powers ... extending to every purpose of the social compact," i.e., every reason why people form governments, and tied that reference in with a latent reference to the Supremacy Clause. Elsewhere, however, Martin wrote of the need of a national bill of rights "prefixed to the Constitution." ${ }^{42}$ It may be that his objection was as to the overgenerality of the principles mentioned in the present Preamble, and that what he would really have liked to have seen, if state declarations and bills of rights were to be preempted, was a Preamble that contained a detailed listing of basic rights. That argument may, however, be difficult to square with his expressed outrage at the perceived destruction of states' sovereignty.

The objection that the Constitution, because of its Supremacy Clause, would render nugatory all states' bills of rights or at least would represent a threat of doing so was well known. George Mason, the delegate from Virginia, had made the point on the floor of the Convention several times. In fact, the last time he maneuvered for the insertion of a national bill of rights into the Constitution was on September 12,1789, the very day on which the Convention was considering the work product of the Committee of Style..$^{43}$ The debate records are, of course, sketchy at best, and one wonders how it was that the delegates were persuaded to oppose Mason's bill-of-rights maneuver. What can be pieced together from the records is that Mason raised the point that a bill of rights could be prepared in a few hours and suggested that if anyone were to move to require one to be inserted in the Constitution, he would second the motion. Elbridge Gerry took the hint and made the motion. Mason seconded it. Roger Sherman of Connecticut, however, pointed out that the

41. Supplement to Max Farrand's The Records of the Federal Convention of 1787) (James H. Hutson, ed. 1987), pp. 291, 292.

42. The Records of the Federal Convention of 1787 , vol. 3, p. 290 (in a letter to Oliver Ellsworth, dated March 19, 1788) (emphasis added).

43. Ibid., vol. 2 , pp. $587,588$. 
state declarations of rights are not repealed by the Constitution, and they could be trusted to do all that a national bill of rights would do. Mason countered with his Supremacy Clause argument, i.e., that national laws were declared to be paramount over state laws, presumably including state bills of rights. Sherman's argument won the day, however, as Gerry's motion was unanimously defeated (the voting, of course, was by states, not by individual delegates). ${ }^{44}$ Mason's Supremacy Clause argument seems quite strong, and one looks in vain in the records of the debates for a rebuttal. Yet there must have been one. The only recorded opposition remark was Roger Sherman's seemingly lame assertion that "the State Declarations of Rights are not repealed by the constitution." 45 More in the way of an explanation must have been given, and indeed the "unanimous" rejection of Gerry's and Mason's motion is not the whole story; there is a mystery connected with the incident-there may have been two votes on the question. ${ }^{46}$ What seems certain, if only because of the mysterious anomaly in the differing reports of the votes on the

\section{Ibid.}

45. Ibid., p. 588.

46. All the records are not in agreement that Gerry and Mason's motion to add a bill of rights to the final version of the Constitution was rejected unanimously. Bancroft has noted that manuscripts and printed texts of the records of the Convention "differ in an astonishing manner." The manuscript version of the Convention's Journal merely reports that the motion "passed in the negative," without indicating unanimity. James Madison's manuscript notes record a vote of 10 aye, 0 nay, and 1 abstention. Yet at least two printed versions of the convention's proceedings record the vote as follows:

On the question for a committee to prepare a bill of rights-New Hampshire,

Connecticut, New Jersey, Pennsylvania, Delaware, aye-5; Maryland, Virginia,

North Carolina, South Carolina, Georgia, no-5; Massachusetts, absent.

Bancroft refers to the anomalous reports as a "change," and indicates that "[t]he change as yet remains a mystery." George Bancroft, History of the Formation of the Constitution of the United States of America (3rd ed. 1883), vol. 2, p. 209. See also Journal of the Constitutional Convention Kept by James Madison (E.H. Scott, ed. 1893), p. 717. Scott's edition of Madison's journal not only reports the 5 aye, 5 nay, 1 absent vote, but also has George Mason arguing that "a general principle ... would be sufficient . . . and with the aid of the State Declarations, a bill might be prepared in a few hours." Ibid. It does not seem inconceivable, in light of the anomalies in the journals and records, that there were two votes: the tie vote, defeating the motion, of course, but also representing the accurate viewpoints of the delegations concerning the need for a bill or declaration of rights, and then, in the aftermath of the tie vote, someone, probably Roger Sherman (the leader of the opposition to the motion) or Gouverneur Morris (the drafter of the new preamble), pointing out the existence of the "Blessings of Liberty" clause and its potential operative effect as a guarantor of the state declaration of rights, and then the second vote unanimously rejecting the motion to prepare a bill of rights. 
bill-of-rights question is that the records do not tell us all that happened, and we are left with the necessity to surmise and infer.

The question involved in the Mason bill-of-rights controversy was as to how the state declarations of rights could be considered secure in view of the Supremacy Clause's assertion that the laws of the United States made pursuant to the Constitution were the supreme law of the land, anything in the Constitution or laws of any state notwithstanding. ${ }^{47}$ The records of the debates on the floor of the Convention, being too sketchy to be useful on the point, leave one with the uneasy feeling that there must have been some unrecorded explanation, perhaps hidden in the simple summary of Delegate Sherman's assertion that the state declarations of rights are not repealed by the Constitution. What in the Constitution itself would support the conclusion that the state bills of rights are not threatened by the Supremacy Clause? The clue may be in the newly revised Preamble inserted by the Committee of Style. The new references to establishing justice, promoting the general welfare, and especially securing the blessings of liberty are references that are usually found in the bodies of bills or declarations of rights. It is not difficult to reconstruct the argument that the state bills or declarations of rights are not undone or threatened by anything in the new national Constitution because the new national Constitution unambiguously proclaims that its purpose is to secure the blessings of liberty, and not to curtail them. On this line of reasoning, the purpose of the "Blessings of Liberty" clause was to serve as an operative buffer preventing the Constitution from being interpreted in such a way as to affect adversely any basic rights of humankind, or at least those basic rights that were then secured by state bills of rights, the point being that the clause itself was intended from the beginning to have operative effect as a tool of constitutional interpretation. ${ }^{48}$

47. U.S. Constitution, Article VI.

48. Alexander Hamilton seemed to see the "Blessings of Liberty" clause in this light, i.e., as a guarantor of the liberties established in states; bills of rights, and even perhaps as constituting a national bill of rights all by itself.

Here, in strictness, the people surrender nothing, and as they retain everything, they have no need of particular reservations. "We the people of the United States, to secure the blessings of liberty to ourselves and our posterity, do ordain and establish this constitution for the United States of America"' (sic). Here is a better recognition of popular rights than volumes of those aphorisms which make the principal figure in several of our state bills of rights, and which would sound much better in a treatise of ethics than in a constitution of government.

... [B]ills of rights, in the sense and in the extent in which they are contended 
George Mason never abandoned his Supremacy Clause objection to the Constitution and, of course, history records that he refused to sign it on that and several other grounds. ${ }^{49}$ What is, perhaps, meaningful in the context of this thesis that the "Blessings of Liberty" clause in the Preamble might have been intended as a response to Mason's incessant argument that the Constitution threatened states' bills of rights is that on the day after Mason had voiced his strenuous objection he presented to the Convention a list of some nineteen suggested revisions of the Committee of Style's version of the Constitution. Not included in the list was a suggestion of the need for a bill of rights. ${ }^{50}$ The suggestion was renewed on September 15, two days later, however. ${ }^{51}$ Whether the "Blessings of Liberty" clause argument, if indeed it was ever made, gave Mason two days' pause in his thoughts on the point is not, of course, recorded. It is evident that the argument (again, if it was ever made) did not allay Mason's concern for long.

There is some evidence, however, that Mason did, indeed, vacillate in his opposition to the Constitution. George Nicholas recounted the incident in a letter to James Madison, dated April 5, 1788:

Mr. Mason ... declared that, notwithstanding his objections to particular parts of the plan, he would take it as it was rather than lose it altogether; since that $I$ have reason to believe his sentiments are much changed which I attribute to two causes: first the irritation he feels from the hard things that have been said of him, and secondly to the vain opinion he entertains ... that he has influence enough to dictate a constitution to Virginia, and through her to the rest of the Union..$^{52}$

It will be remembered that Mason was the author of the Virginia Declaration of Rights, mentioned earlier. ${ }^{53}$ If Mason was, indeed, trying to get the Convention to adopt a Virginia-type Declaration of Rights for the United States Constitution, and if the Committee of Style put the clause about securing the blessings of liberty to ourselves and our posterity into the Preamble in a last minute (albeit eventually

for, are . . . unnecessary in the proposed constitution. . . .

Alexander Hamilton, The Federalist No. 84 (Jacob E. Cooke, ed. 1961), pp. 578, 579.

49. The Records of the Federal Convention of 1787, pp. 636-40.

S0. Ibid., vol. 3, pp. 269-71.

51. Ibid., vol. 2, p. 637.

52. Ibid., vol. 3, p. 296.

53. The Federal and State Constitutions, Colonial Charters, and Other Organic Laws of the United States, p. 1098. 
unsuccessful) effort to gain Mason's support for the final version of the document, as seems likely, then there would seem to be some connection, in the context of legislative history, between the "Blessings of Liberty" clause and the Virginia Declaration of Rights. It will be remembered that the Virginia Declaration of Rights, antedating the Declaration of Independence by a month in 1776, contained perhaps the original reference to "posterity" in the context of the governmental documents that were emerging from the freedom movements in the colonies-becoming-states. The references to "posterity" in the Virginia Declaration are particularly strong:

A Declaration of Rights made by the Representatives of the good people of Virginia, assembled in full and free convention; which rights do pertain to them and their posterity, as the basis and foundation of Government.

1. That all men are by nature equally free and independent, and have certain inherent rights, of which, when they enter into a state of society, they cannot, by any compact deprive or divest their posterity; namely, the enjoyment of life and liberty, with the means of acquiring and possessing property, and pursuing and containing happiness and safety. ${ }^{54}$

If the Virginia Declaration of Rights did inform and influence the Committee of Style in the drafting of the Preamble to the Constitution of the United States, ${ }^{55}$ then it would seem appropriate to look to the Virginia Declaration for an understanding of the operative force of the use of the term "Posterity." According to the Virginia Declaration, rights to the enjoyment of life and liberty cannot be ceded to society, nor can persons cede those rights on behalf of their posterity. The rights to life and liberty are, in the words of the Declaration of Independence, "unalienable." The meaning is the same. They cannot be alienated or conveyed away to the state or to anyone else, and this inalienability applies not only to our own basic rights, but also

54. The Virginia Declaration of Rights, as agreed to by the Virginia Convention on June 12, 1776; reproduced in The George Mason Lectures: Honoring the Two Hundredth Anniversary of the Virginia Declaration of Rights (1976), appendix 20 (emphasis added). See also The Federal and State Constitutions, Colonial Charters, and Other Organic Laws of the United States, p. 957.

55. It is not doubted that some of the immediate verbiage of the Preamble was taken from Article III of the old Articles of Confederation, which has the states entering into a "firm league of friendship with each other, for their common defence, the security of their liberties, and their mutual and general welfare," but the Constitution's Preamble so clearly speaks to people's rights, and specifically not states' rights, that the conceptual antecedent cannot possibly be in the Articles of Confederation. The Articles, because they had no occasion to do so, did not mention "posterity." 
to those of our posterity. Moreover, the basic rights enumerated in virtually all bills or declarations of rights invariably include rights to life and liberty.

\section{Posterity and Moral Philosophy}

It has not been the purpose of this article to make the case for a philosophical grounding of society's duty towards its "posterity.", The case from philosophy would amount to a natural-law-type argument. This article is confined to a positivist approach, pointing to the acceptance, by the framers of the Constitution and by the people who accepted it as their fundamental law, of a purpose of securing the blessings of liberty to their descendants on into the indefinite future, i.e., an acceptance of the proposition that the Constitution is to be interpreted in a posterity-oriented manner. It is one thing, however, to make the case that the Framers and our constitutional ancestors had that intent, but it is another thing to demonstrate that that intent is consistent, or at least not inconsistent, with moral theory. Interpretive principles, however, consistent they may be with original intent, are suspect in the minds of many if they are inconsistent with moral theory.

To some it may seem obvious, perhaps self-evident, that an extant generation, acting as a society, has a moral duty to care about, or at least to avoid harming, the interests of succeeding generations. ${ }^{56}$ The parent-child analogy raised to the generalized level of society would seem compelling. The case should, perhaps, nonetheless be made.

One who has made such a case is John Rawls. Rawls, a moral philosopher of the contractarian and Kantian (therefore rationalist) school, posited the now famous veil-of-ignorance device as part of his original-position analysis of justice and its fundamental precepts. Rawls' idea is that the fundamental principles of justice which are to govern a society can be arrived at by hypothesizing a group of original "justice seekers" who are motivated by a rational self-interest

56. Christopher Lasch observed, a decade ago, that:

we are fast losing the sense of historical continuity, the sense of belonging to a succession of generations originating in the past and stretching into the future[,] and that we are now experiencing an "erosion of any strong concern for posterity."

Christopher Lasch, The Culture of Narcissism (1979), p. 30, cited and quoted in R. George Wright, "The Interests of Posterity in the Constitutional Scheme," $59 U$. Cin. L. Rev. (1990), pp. 113, 125. 
in trying to come up with the fundamental principles which will govern them as a society, but who are also under a "veil of ignorance" - none of them knows his or her place in society, social status, or personal attributes, i.e., the factors which lead to inequality or favoritism, and therefore to injustice. ${ }^{57}$ The result should be a rationally arrived at and realistic set of general precepts of justice.

One of the factors which Rawls specifies as being occluded by the veil of ignorance in this scheme is one's generational identity: "The persons in the original position have no information as to which generation they belong." 58 In this way, it is thought, no principle of justice will come into being which is unfair to succeeding generations. It is a way of arriving at intergenerational justice. None of the justice seekers in the "original position" will be likely to posit an understanding of justice which will be unfair to future generations because the hypothetical justice seeker does not know whether he or she (gender too is unknown) might be a member of the future generation. Rawls explains, in the context of immediately succeeding generations:

The question arises ... whether persons in the original position have obligations and duties to third parties, for example, to their immediate descendants. To say that they do would be one way of handling questions of justice between generations. However, the aim of justice as fairness is to derive all duties and obligations from other conditions, so this way out should be avoided.... What is essential is that each person in the original position should care about the well-being of some of those in the next generation, it being presumed that their concern is for different individuals in each case. Moreover for anyone in the next generation, there is someone who cares about him in the present generation. Thus the interests of all are looked after and, given the veil of ignorance, the whole strand is tied together. ${ }^{39}$

57. One might surmise that Rawls took a clue from Rousseau, who defined a nation's ideal "lawgiver" as:

a superior intelligence, who could understand the passions of men without feeling any of them, who has no affinity with our nature but knew it to the full, whose happiness was independent of ours, and who would nevertheless make our happiness his concern, who would be content to wait in the fullness of time for a distant glory, and to labor in one age to enjoy the fruits of another.

Jean Jacques-Rousseau, The Social Contract (M. Cranston, trans. 1968) p. 84. Rawls had other precursors as well. See Raymond B. Marcin, "Justice and Love," 33 Cath. U. L. Rev. (1984), pp. 363, 372-82.

58. John Rawls, A Theory of Justice (1971), p. 137.

59. Ibid., pp. 128, 129. 
In Rawls' scheme of things, one generation does not have a direct obligation or duty to its immediate descendants. The idea of a direct obligation or duty would lead to endless arguments over the content of the obligation or duty. The duty or obligation is derived indirectly through the use of the original-position device. The end result seems to be an inter-generational "golden rule"; we must do unto the next generation as we would do unto ourselves. Just as the biblical golden rule specifies no particular content, yet seems to be bursting with self-evident meaning and operative significance, so too does this intergenerational application of the original-position methodology of Rawls seems to lead inexorably to a forward-looking and progressively protective attitude towards posterity.

Just as, in this article, a relatively modest claim has been advanced with respect to the interpretation of the "Blessings of Liberty to . . . our Posterity" clause in the Preamble, so too Rawls' application of the original-position methodology to future generations is relatively modest in scope.

[T]he original position is not to be thought of as a general assembly which includes at one moment everyone who will live at some time; or, much less, an assembly of everyone who could live at some time. It is not a gathering of all actual or possible persons. To conceive of the original position in either of these ways is to stretch fantasy too far; the conception would cease to be a natural guide to intuition. ${ }^{60}$

In the same way, the argument has been advanced in this article that the "Blessings of Liberty to ... our Posterity" clause is best interpreted not as directly securing those blessings to all yet-to-beborn or yet-to-be-conceived members of posterity, but rather as an interpretive aid, a posited guide to intuition when we are faced with fundamental questions as to the meaning and scope of basic concepts set forth in the Constitution.

Rawls never applied his original-position analysis to the specific problem which is the subject of this article. His major example was in the area of economic intergenerational justice. ${ }^{61}$ His words and his allusions, however, would seem to have implications in many other contexts:

[I]magining themselves to be fathers, [the justice-seekers] are to ascertain how much they should set aside for their sons by noting

60. Ibid, p. 139.

61. Ibid., pp. 284-93. 
what they would believe themselves entitled to claim of their fathers. ${ }^{62}$

If justice-seekers are to put themselves hypothetically in the position of Rawls' yet-to-be-born sons for the purpose of devising economic principles which will be fair to the next generation, it would seem an a fortiori point to suggest that a similar hypothetical positioning is warranted when the principle at issue is life itself. Rawls' approach to intergenerational justice has been critiqued. ${ }^{63}$ It and approaches like it have, however, proven useful in theses concerning protection of the environment, economic waste, and other phenomena affecting yet-to-be-born people. ${ }^{64}$

\section{Conclusion}

In recognizing the right to privacy in the abortion decision on terms so broad as to amount to a virtually unlimited right to abortion on demand, the Roe decision, it would seem, has failed to secure the blessings of liberty to a portion of our posterity. Some might be inclined to argue that the Roe decision has deprived a portion of our posterity of the inalienable right to life. In light of the legislative history of the "Blessings of Liberty ... to our Posterity" clause, both propositions would seem to be tenable. To some, of course, neither proposition will seem persuasive. What cannot be gainsaid, however, is that the Roe decision neglected one small bit of relevant input, i.e., the fact that we, the people, ordained and established the Constitution not only to secure the blessings of liberty to ourselves, but also to secure those very same blessings to our posterity. ${ }^{65}$ Our

62. Ibid., p. 289.

63. See Richard A. Epstein, "Justice Across the Generations," 67 Tex. L. Rev. (1989), pp. 1465, 1466.

64. "The Interests of Posterity in the Constitutional Scheme," pp. 113, 125, and authorities cited therein.

65. Thomas Paine, no stranger to the use of the word "posterity" (he used it ten times in his 1776 pamphlet Common Sense), once captured the sensibility behind a people's orientation towards posterity, albeit in a different context and at an earlier time, when he retold the following anecdote:

$I$ once felt that kind of anger, which a man ought to feel, against the mean principles that are held by the tories: A noted one, who kept a tavern at Amboy, was standing at his door, with as pretty a child in his hand, about eight or nine years old, as I ever saw, and after speaking his mind as freely as he thought was prudent, finished with this unfatherly expression, "Well, give me peace in my day." Not a man lives on the continent but fully believes that a separation must some time or other finally take place, and a generous parent should have said, "If there must be trouble, let it be in my own day, that my child may have peace"; and this single reflection, well applied, is sufficient to 
Constitution proclaims itself to be posterity-oriented. We, in that Constitution, have proclaimed ourselves to be a posterity-oriented people. The problem with the Roe decision from a positivist perspective is that, at best, it failed to take that textually specific posterity orientation into account; at worst, it denied it. In either case the Roe decision is wanting.

If $R o e$ is to be overturned, the decision overturning it will almost certainly be positivist in tone, i.e., confined to fair interpretations of the concepts and principles announced in the Constitution itself. If, beyond being positivist in tone, it is also thorough in scope and takes into account the Constitution's expressed value orientation towards posterity's enjoyment of the blessings of liberty, it may be a pro-life decision as well.

awaken every man to duty.

Thomas Paine, The Crisis, Number I (1776), reprinted in Thomas Paine, Political Writings (Bruce Kulick, ed. 1989), pp. 44, 45 (emphasis in original). 
